Article

\title{
Green Streets to Serve Urban Sustainability: Benefits and Typology
}

\author{
Joowon Im(1) \\ Program of Landscape Architecture, College of Architecture, Planning and Public Affairs, \\ University of Texas at Arlington, Arlington, TX 76010, USA; joowon.im@uta.edu
}

Received: 1 September 2019; Accepted: 13 November 2019; Published: 18 November 2019

\begin{abstract}
Urbanization and climate change have impacted the ecosystems of the US cities. Impervious surfaces in the urbanized areas are a critical issue for both challenges and green infrastructure can be an alternative solution to achieve urban sustainability. Green infrastructure protects urban ecosystems by reducing imperviousness as treating stormwater runoff and providing other multifaceted benefits. However, even with the great potential, its adoption is still discouraged due to limited understanding and guidance especially for the cities with a growth-driven policy. This paper proposes that green infrastructure, particularly green streets in relation to impervious surfaces, can deliver urban sustainability by providing a better understanding to promote the acceptance and successful adoption of green streets through literature review and case studies in the US. Green streets are primarily implemented within the right-of-way and facilitate stormwater treatment along with diverse street designs providing multiple benefits such as flood management, wildlife habitat and natural pathway creation, neighborhood beautification, cost-effective solution, and more. The defined green street typology in this paper is an important tool for communicating among planners and the public by providing form-based standardized classification. Green streets can be utilized as a sustainable development approach, fulfilling a variety of environmental, social, and economic objectives.
\end{abstract}

Keywords: green street; green infrastructure; urban sustainability

\section{Introduction}

Urban sustainability in the US is at risk as the ecosystems of cities have been impacted by increasing population density in urban areas [1], further challenged by climate change such as extreme weather conditions (e.g., urban flooding, droughts) [2]. Rapid development in cities with high population density results in the increase of impervious surfaces (e.g., paved surfaces, building footprints) that affect urban ecosystem with excessive stormwater, accumulation of pollution in streams [3,4], and temperature increase (e.g., urban heat island) [5]. Extreme weather conditions such as urban flooding causes massive destruction on infrastructure, economics, and human lives in affected regions [6] while heat waves make people ill and die as exposed to extreme temperature for a longer period of time [7]. While impacts of extreme weather are aggravated by the excessive imperviousness leading to extreme flooding events [8] and heat waves [7], the consequences of urbanization and climate change ultimately threaten human well-being and our environment.

In regard to the mitigation of such conditions in urban cities, green infrastructure can provide an alternative solution by treating and reducing impervious surfaces to amend and improve already challenged urban ecosystems by using natural materials such as soils and plants. Adopting green infrastructure can promote sustainable urban ecosystems by increasing vegetation with greater biodiversity, improving well-being by promoting more green space [9], and climate resiliency by treating stormwater [10] and urban heat island effects [11]. 
However, despite its affordable and multifunctional benefits that can prove to be very effective solutions [12], its application is sometimes discouraged due to lack of comprehensive guidance [13] and "lack of understanding and knowledge of what green infrastructure is and the benefits it provides" [14] (p. 2). Thus, this paper focuses on green streets (also called green alleys), one of the eleven elements of green infrastructure as recognized by the US Environmental Protection Agency (EPA) (apart from downspout disconnection, rainwater harvesting, rain gardens, planter boxes, bioswales, permeable pavements, green parking, green roofs, urban tree canopy, and land conservation). In addition to the potential benefits that municipalities and institutions intend to provide in the US, this paper focuses on examples in the US to fill the gap in the scholarly literature lacking topics primarily dedicated to green streets in the US. Given the fact that the sum of the US public roads and streets is about 4,146,410 miles long [15], almost half of urban areas are dedicated to streets, highways, and parking areas [16], and roads are primary reasons related to issues of impervious surfaces [17], studying and promoting green streets can be an effective solution for issues related to impervious surfaces among other elements of green infrastructure. Street greening projects without stormwater management consideration were not treated in this paper. The goal of this paper is to provide a better understanding about green streets of comparatively recent development approaches for those concerned with urban ecosystems with interests in implementing such projects and also for members of the public who have little knowledge about what green streets are and how they can benefit communities [18]. The long-term goal is to help promote the acceptance and successful adoption of the green streets by probing its potential as a sustainable strategy in achieving livable and healthy communities in urban cities. This study investigates various definitions, objectives, and types of stormwater treatment facility designs as outlined mainly in selected manuals. The author then discusses future green street studies by taking into account case study projects and their applications from other countries while examining the roles of green streets in the context of sustainable development paradigms.

\subsection{Definition of a Green Street}

Green streets in the US are known as on-site solutions installed primarily in the public right of way (public street/passage) to treat polluted stormwater runoff generated from impervious surfaces and conveyed to local waterways without filtration [16]. The implementation of green streets on the public right of way is often times easier than the implementation on private streets due to ownership issues. It mainly reduces impervious surfaces by adding more vegetation to increase permeable areas for treating stormwater runoff, which is one of the key design components of green streets not featured in conventional street designs. As a stormwater treatment measures, the construction of green street impacts appearances of streets and technical applications in different ways, depending on the types of pollutants, available space, land uses, and community needs that are involved.

Green street manuals and websites of various cities and agencies implementing this approach are used to arrive at a common understanding of how green streets are defined (Table 1). Aspects of green streets were generally agreed on: (1) They are implemented within the right of way, (2) they are a means of treating stormwater runoff, and (3) the adopted stormwater treatment process includes vegetation and soil beds. In sum, the great majority of the definitions depict a green street as a sustainable stormwater treatment practice that is mainly implemented in the right-of-way and includes the utilization of natural materials for this purpose. As an example, Portland, OR is one of pioneering cities that adopted green streets, with the first green street project being implemented as early as 2003 [19]. The city approved the green street approach in public and private development in 2007. The working definitions of this approach used by Portland Environmental Services and Metro (Portland Metropolitan Area) primarily emphasize stormwater treatment and watershed health. Most other cities in Table 1 which are now adopting projects of this nature also appear to view them as a means of stormwater management and to be working from a definition of green streets that is similar to Portland's. While the definitions primarily emphasize stormwater management functions, there is 
some variability in the objectives of green street projects across the country, depending on the goals of the individual cities to be discussed in a later section.

Table 1. Definition of green streets.

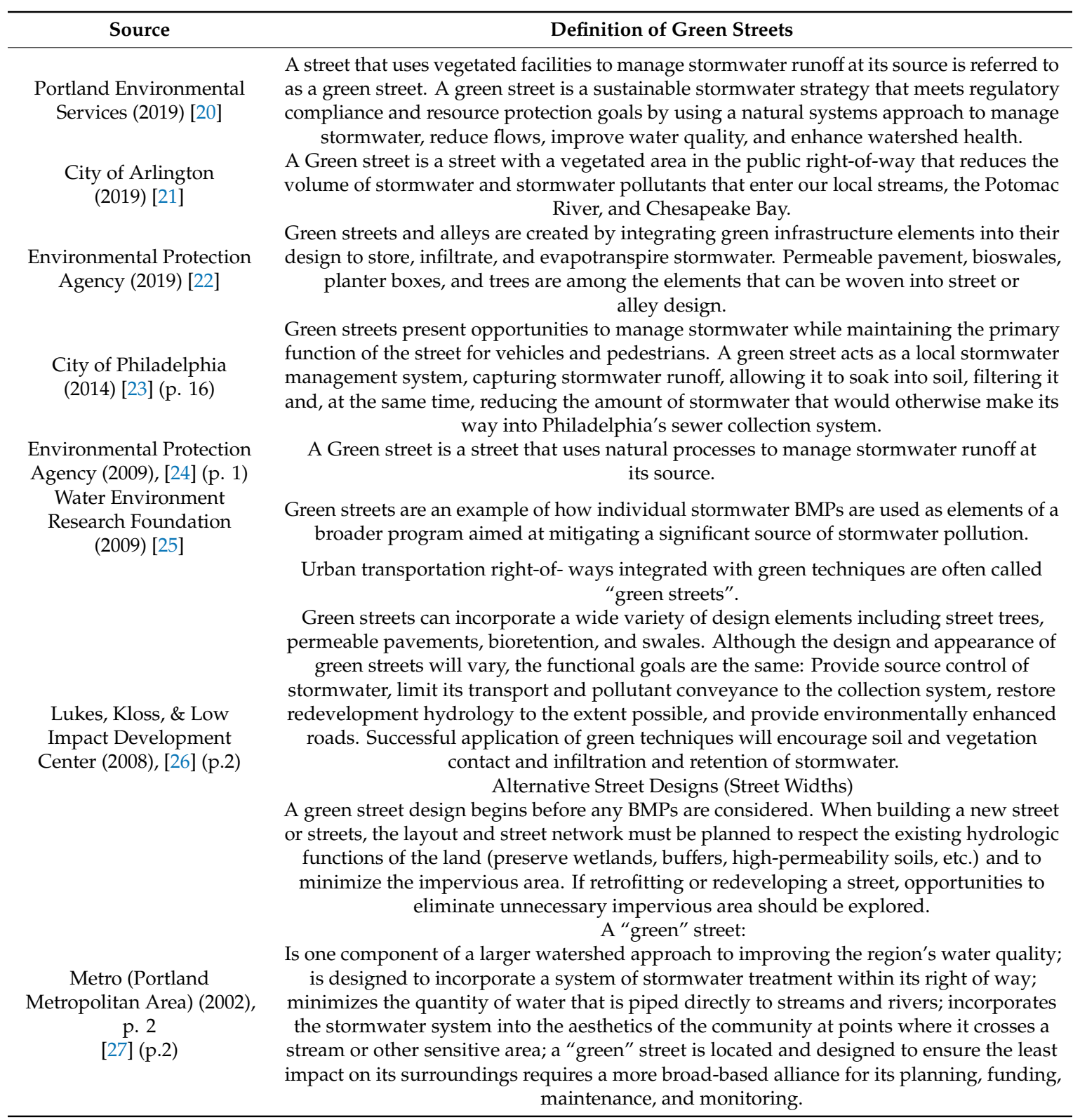

\subsection{Green Street versus Street}

The definition of a street according to Cambridge Dictionaries Online is "a road in a city or town, usually with buildings along one or both sides." Conventional streets are seldom integrated with stormwater treatment systems or connected to open spaces; they are automobile-oriented thoroughfares with a high proportion of impervious surfaces and decreased pedestrian safety [28], and they utilize prescribed street standards that limit the type of multifunctional adaptation considering the pedestrians' use of the street.

In contrast, green streets can be distinguished from typical streets in a number of respects (Table 2). As noted by the EPA, green streets incorporate integral stormwater treatment systems that are designed to improve the water quality and reduce the quantity of runoff [22]. In most cases, they are also connected with open spaces [29] and intended to be pedestrian-oriented for the purpose of supporting 
a safer and healthier community [20,23]. Green streets are implemented with less impervious surfaces than conventional streets because they feature narrower roads and wider planting beds (which create more available permeable surfaces); green streets also provide a safer walking environment for local residents [24]. In addition, green streets potentially allow flexibility for planners and designers to come up with designs that meet local needs. For instance, integrated stormwater treatment facilities can be of different sizes, and the plants used can be varied to suit local climate conditions, as suggested in numerous green street manuals.

Table 2. Street versus green street.

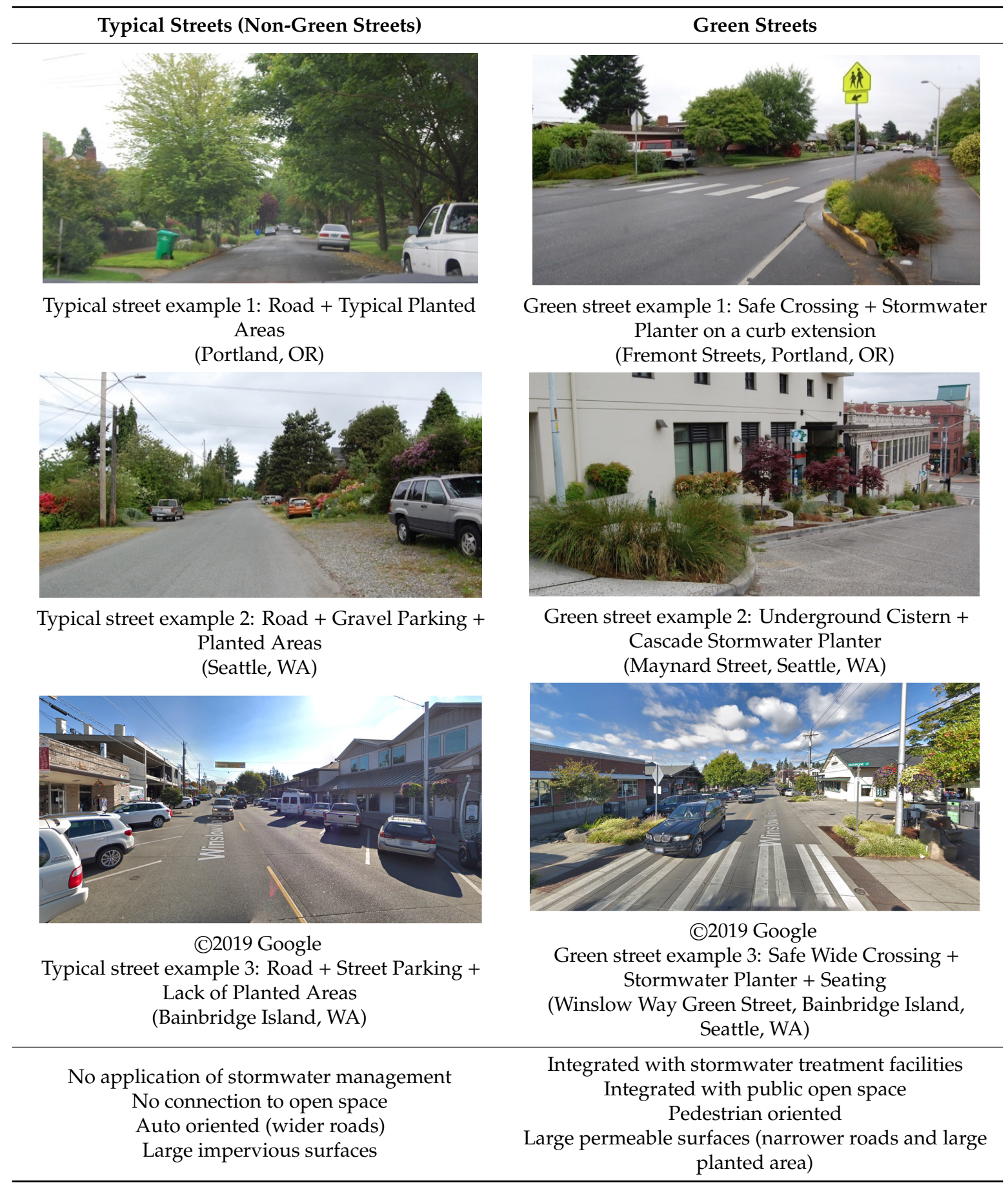


Green streets, however, also need to retain their traditional function as streets because, although they may have design applications for a better community, they are implemented in the right of way. Streets are one of the key elements that physically comprise a city and can be exciting places "where people walk, shop, meet, and generally engage in the diverse array of social and recreational activities that, for many, are what makes urban living enjoyable" [30] (p. 283). Streets are also important elements that connect one point to another, substantially forming and shaping a city. Streets run between private and public spaces, conveying both pedestrians and vehicles from one place to another. Thus, the benefits of integrated elements of streets are distributed throughout the adjacent communities and to the people who use and live on the streets. Therefore, streets can help form the character of a city influencing its culture and history. They, along with building footprints, comprise one of the largest areas of impervious surfaces in an urban area, and impervious surfaces are a useful measure for other features such as the water quality in local streams in relation to stormwater runoff generated from them [31]. Moreover, the flow of water is affected by the patterns of streets [26]. Thus, important roles of streets need to be considered with the adoption of green streets including proper facilities (stormwater management, street furniture, vegetation strips, and other recommended facilities and design features) implemented within the context of the larger street network: Applying the effective and creative approach of green streets should be an useful strategy for resolving urban runoff problems generated from impervious surfaces in a more sustainable way as providing multiple benefits.

\section{Materials and Methods}

This paper primarily adopts a descriptive case study with a multiple-case design that will require investigating the phenomenon in various cases [32] such as green street manuals and constructed projects for the analysis. The primary data source for this study consists of manuals dedicated solely to green street applications; only manuals with a specific focus on such projects have been selected so that the contexts to which they refer are rigorously related to green street implementation regarding objectives and design applications. The selected manuals were primarily created by the federal, municipal agencies, or related research foundation/organizations including the corresponding codes and ordinances. Manuals were searched by such key words as green street manual and green alley manual via search engines (e.g., Google and Bing). The search engines were more efficient than using any academic databases since they were not scholarly literature but uploaded to websites or databases created by government or non-profit agencies. The primary manuals used here can be found in Table 3 . In addition to the data from these manuals, data from site visits to constructed/in-progress green street projects were included, along with webpages and reports of green street cases from different cities and agencies, to ensure the breadth of the data used.

Table 3. List of manuals.

\begin{tabular}{ccc}
\hline Author & Type/Agency & Place \\
\hline Pioneer Valley Planning Commission, 2015 [33] & Manual/ & Nonprofit \\
City of Philadelphia, 2014 [23] & Design Manual/ \\
Municipality & Manual/ \\
Municipality & Philadelphia, PA \\
District Department of Transportation, 2014 [34] & Washington, DC \\
Carlson, Caughey, \& Ward, 2014 [35] & $\begin{array}{c}\text { Municipality } \\
\text { Manual/ } \\
\text { City of Cleveland, 2013 [36] }\end{array}$ & Holyoke, MA \\
City of Seattle, 2012 [29] & Manicipality & Cleveland, OH \\
& Municipality & Seattle, WA \\
\hline
\end{tabular}


Table 3. Cont.

\begin{tabular}{ccc}
\hline Author & Type/Agency & Place \\
\hline Chicago Department of Transportation, 2010 [37] & Handbook/ & Chicago, IL \\
US Environmental Protection Agency, 2009 [24] & $\begin{array}{c}\text { Munipality } \\
\text { Design Manual/ } \\
\text { Federal }\end{array}$ & Washington, DC \\
Water Environment Research Foundation, 2009 [25] & $\begin{array}{c}\text { Design Manual/ } \\
\text { Nonprofit }\end{array}$ & Alexandria, VA \\
Lukes, Kloss \& the Low Impact Development Center, 2008 [26] & $\begin{array}{c}\text { Handbook/ } \\
\text { Federal } \\
\text { Metro Portland, 2002 [27] }\end{array}$ & Wanual/ \\
& Municipality & Portland, OR \\
\hline
\end{tabular}

There were two sets of analyses: (1) A descriptive study of goals and objectives to investigate the breadth of benefits that can be generated by adopting green streets and (2) a descriptive study of green street design typologies focusing on stormwater facilities, which is one of prominent characteristics, to understand physical application of green streets within the right-of-way. An analysis based on phenomenological method suggested by Ratner [38] is conducted to identify accurate themes through multiple iteration by forming staged structures that require a rigorous analysis of the content of the data. All the contents related to objectives and benefits in the manuals were collected and "meaning units" [38], which contain specific meaning of a certain idea, were identified. Then, each identified meaning unit was summarized and grouped based on relative agendas (subcategory). The identified lists have been grouped and categorized again to get higher level criteria (top category) that can represent the lists that belong to the lower stage.

The definitions of a green street and general differences between green streets and typical streets were evaluated to understand the specific characteristics of green streets in the previous chapter. With the analysis, a closer look at the list of objectives in the green street manuals provided the basis for discussion about primary characteristics and the breadth of potential benefits for the surrounding communities. Typologies of green street designs applied to green street projects, especially those involving stormwater treatment facilities, were categorized according to different design applications and locations where they were placed. Once the typologies were defined, a member check process was conducted with experts who worked on green street projects from governmental or non-profit agencies. The typologies were presented to the experts, whose feedback helped to modify and improve them to increase the validity of the created typologies. Overall, this paper aims to provide a comprehensive understanding of what green streets are and to work toward promoting green streets with consistent design approaches that can provide successful implementation with more benefits.

\section{Results}

\subsection{Potential Benefits of Green Street}

Thirty-six items in an exhaustive list of benefits (subcategory) were identified from the first-round analysis derived from the objectives and definitions in the manuals. Five themes (top category) were identified as higher level criteria upon summarizing and grouping subcategories (Figure 1): Stormwater management (at its source), environmental preservation and improvement, social improvement, transportation enhancement, and economic efficiency. Among the identified benefits grouped under the five themes, significant benefits were found based on the frequency mentioned in the manuals, in particular, stormwater quality improvement (1), stormwater volume reduction (2), stormwater infiltration (3), stormwater capture and store (4), basement alleviation and flood management (5), utilization of soils and vegetation (7), connection to landscape areas and natural areas (9), wildlife habitat and natural pathway creation (10), urban heat reduction (11), neighborhood beautification (21), pedestrian experience and safety enhancement (27), urban street design and function improvement (30), 
and cost effective solution for stormwater management (34). As stated, benefits related to stormwater management were the most frequently mentioned elements in the manuals. The overall elements are not limited solely to stormwater treatment but also include a range of environmental, social, and economic aspects, indicating that green streets are clearly expected to provide a number of benefits in addition to stormwater treatment.

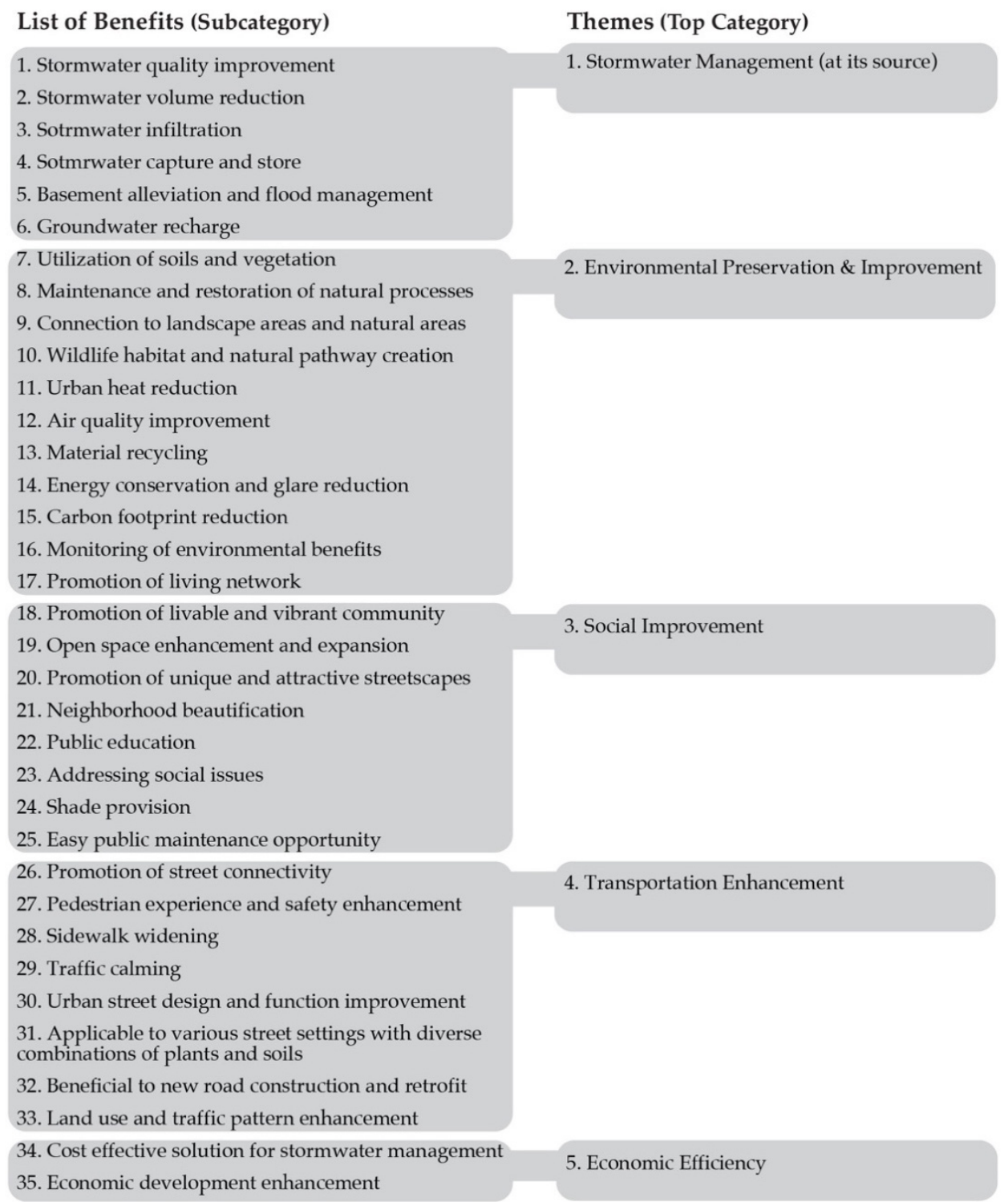

Figure 1. List of potential benefits derived from the selected manuals.

\subsection{Green Street Typology: Form-Based Approach}

Many municipalities that are adopting green streets describe their design, specifications, and applications in a set of manuals, standards, municipal plans, and online databases: Philadelphia, PA has the Green Streets Design Manual and the green street information provided on the Philadelphia Water Department website; New York published green street information in its NYC Green Infrastructure Plan, along with design standards from the city's Parks Department and Environmental Protection Agency; Portland, OR's green street information is provided under their Sustainable Stormwater Management initiative; and Seattle, WA, defines green streets in its Right-of-Way Improvement Manual, which also covers its Green Stormwater Infrastructure approach. 
Those design standards published by various municipal agencies provide technical designs for the green street stormwater treatment systems that generally include items such as the sizes of the different types of stormwater treatment facilities involved, inlet designs, plant selection, soil combinations, and other related technical and design specifications. In order to deliver the potential benefits that are frequently discussed in the manuals, these items need to be integrated with contexts of streets where any given green street projects are applied.

It is important to note that each of the manuals and design standards selected for the research has adopted various types of green street practices that they refer to under slightly different terms (Table 4). Thus, the author first categorized stormwater treatment measures applied to green street projects depending on where they are located within the right of way and their structural shapes based on the manuals. This approach to categorization was possible because each manual actually shares quite similar types of green street facilities, despite the various ways they were referred to. Then, a list of green street practice types and typologies were created to help develop a better understanding of current practices and techniques and thus facilitate communication efficiently among designers and planners based on the different facility types in the design manuals and case study projects (Table A1). The form-based categorization for deriving typologies was taken into account for defining different types of green street practices integrated into street network systems (Figure 2). Here, the types are divided first according to whether the practice is applied at an intersection, midblock, or both (a combination), then subdivided based on whether the facility was located within the sidewalk or extended outward from the curb towards the roadway. After the different shapes of facilities have been listed, permeable paving, runnels (open/closed), cisterns (above/underground), fountains, street furniture, and structures are then categorized as special applications of green street practices based on constructed green street projects studied.

Table 4. Green street typology and terms from selected manuals.

\begin{tabular}{|c|c|}
\hline Manuals & Green Street Typology and Terms \\
\hline $\begin{array}{l}\text { City of Philadelphia (2014), [23] } \\
\text { (pp. 24-37) }\end{array}$ & $\begin{array}{ll}\text { - } & \text { Stormwater planter } \\
\text { - } & \text { Stormwater bump-out } \\
\text { - } & \text { Stormwater tree } \\
\text { - } & \text { Stormwater tree trench } \\
\text { - } & \text { Permeable pavement } \\
\text { - } & \text { Green gutter } \\
\text { - } & \text { Stormwater drainage well }\end{array}$ \\
\hline $\begin{array}{l}\text { District Department of } \\
\text { Transportation (2014), [34] (p. 10) }\end{array}$ & $\begin{array}{l}\text { - Permeable pavement: Permeable unit pavers, pervious concrete, } \\
\text { porous asphalt, porous rubber } \\
\text { Bioretention: Bioretention planter adjacent to roadway, curb } \\
\text { extension, bioretention in open area, bioswale. } \\
\text { - Tree Space: Small, medium, large trees }\end{array}$ \\
\hline $\begin{array}{l}\text { City of New York, Department of } \\
\text { Environmental Protection, \& } \\
\text { Bureau of Engineering Design and } \\
\text { Construction (2017), [39] (pp. 1-2) }\end{array}$ & $\begin{array}{ll}\text { - } & \text { Right of way bioswale (with variable sizes) } \\
\text { - } & \text { Right of way Greenstrip (with variable sizes) } \\
\text { - } & \text { Right of way infiltration basin with concrete top (with } \\
\text { variable sizes) } \\
\text { - } & \text { Right of way infiltration basin with grass top (with variable sizes) }\end{array}$ \\
\hline $\begin{array}{l}\text { Portland Environmental Services } \\
\text { (2016), [40] (pp. 2-175) }\end{array}$ & $\begin{array}{ll}- & \text { Swale } \\
\text { - } & \text { Planters } \\
\text { - } & \text { Curb extensions } \\
\text { - } & \text { Tree well }\end{array}$ \\
\hline $\begin{array}{l}\text { Lukes, Kloss, \& Low Impact } \\
\text { Development Center (2008), [26] } \\
\text { (pp. 3-7) }\end{array}$ & $\begin{array}{ll}\text { - } & \text { Swale } \\
\text { - } & \text { Bioretention curb extension and sidewalk planter } \\
\text { - } & \text { Permeable pavement } \\
\text { - } & \text { Sidewalk trees and tree boxes }\end{array}$ \\
\hline
\end{tabular}




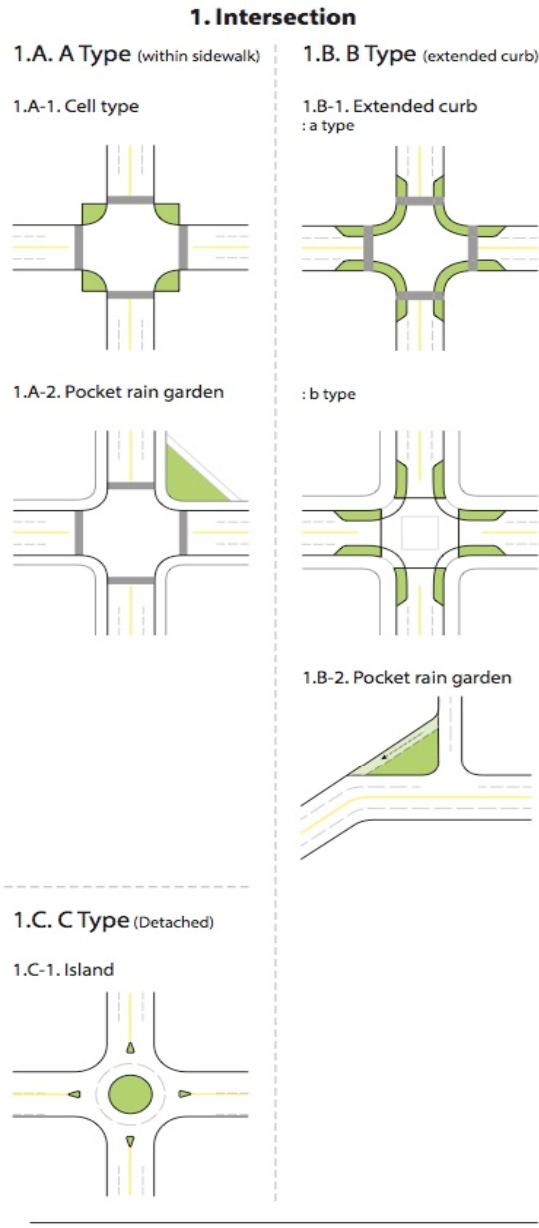

4. Other Applications

4.A. Permeable paving

4.B. Runnel (open/covered)

4.C. Cistern (above/underground)

4.D. Fountain

4.E. Street furniture

4.F. Structure (shade/wall)
2. Midblock

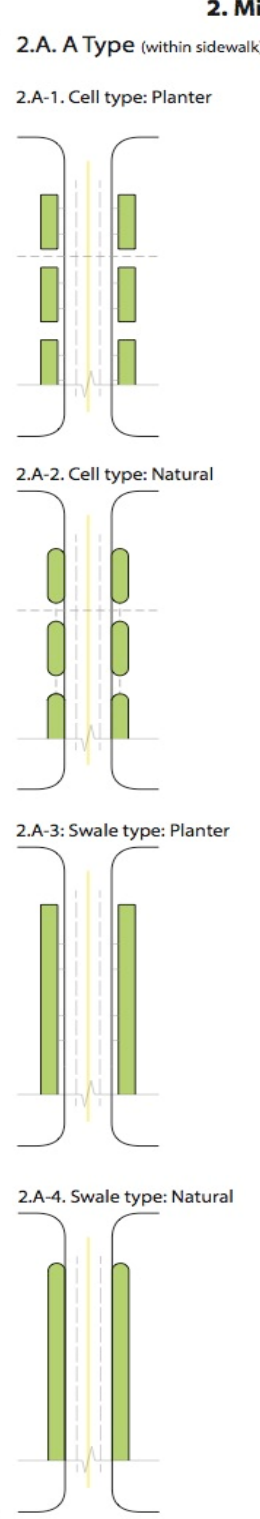

3. Combination

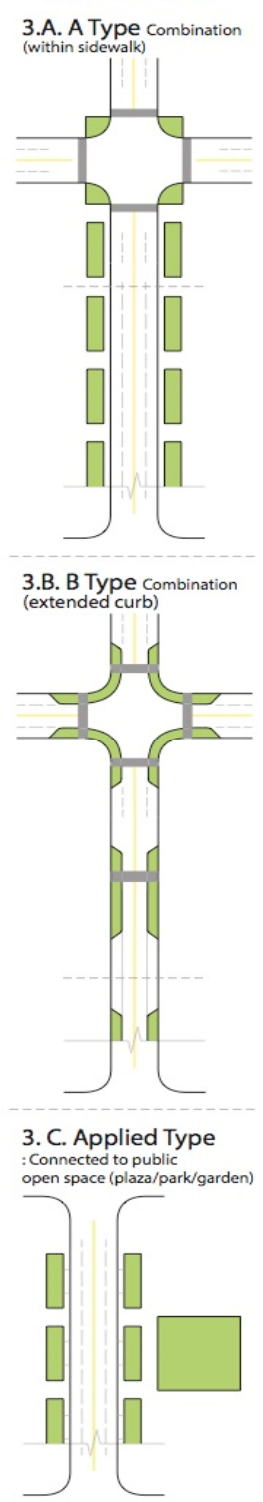

Figure 2. Form-based green street typology.

The green areas in Figure 2 indicate where green street stormwater facilities are located. In these areas, stormwater runoff is treated with plants and soils. An overflow and underdrain system with perforated pipes should be considered as well. At a street intersection, stormwater treatment facilities can be implemented on all four corners. They can be located within the curb (1.A-1. cell type) or extended from the curb (1.B-1, 2. extended curb: a type, $\mathrm{b}$ type). One of the benefits of extended curb type is that it can provide safer pedestrian crossing by reducing the crossing distance and introducing a traffic calming effect. If the stormwater treatment structure is a cell type (normally a singular facility) but has a more organic shape than the usual rectangular shape, it is categorized as a pocket rain garden (1.A-2, 1.B-2). These are typically found in isolated areas such as gore points (normally a triangular shape) and areas close to intersections rather than the midblock of streets. The pocket rain garden can be conveniently implemented in a smaller area but may be less effective in treating stormwater runoff compared to the cell type or the swale type in the midblock. It can also serve as a small community park with additional design features such as benches and shade structures. The island type (I.C-1) can be a focal point in the area to promote a better image of a city with beautification while accepting and treating stormwater runoff from the surrounding roads. 
In the midblock area of a street, if a facility is small and repeated in one or more blocks, it is referred to as a cell type (2.A-1,2), which can be divided into two forms: A planter form or a natural form. The walls of the planter form are made of durable materials such as concrete and are often rectangular in shape. The walls of the natural form are constructed with more raw materials such as soils and stones and have more natural/organic shapes than the planter form. The cell type can be accepted better by the users since its form is similar to the conventional street planters. Each cell can be connected with an overflow system for optimized stormwater runoff treatment. It can then provide continuous planting bed for providing greenness and community beautification. The cell type can also provide better access utilizing spaces in between planters, such as pedestrian movement from the sidewalk to street parking. If the stormwater treatment facility is linear and long, it is labelled a swale type facility $(2 . A-3,4)$. These can again be subdivided into a planter form and a natural form depending on the materials used and the type of construction as mentioned above. The swale type can be more efficient in treating stormwater runoff since it has more contact area with stormwater than the cell type, however, it may obstruct pedestrian movement on the street because it lacks breaks along the linear facility. Similar to the cell type in the midblock, the covered cell type (2.A-5) appears in the conventional form of a planter. Extended curb (2.B-1) and median types (2.C-1) are also implemented in the midblock and can provide safer pedestrian crossing as making the crossing distance shorter.

The combination types (3.A, 3.B, 3.C) are composed of types in the intersection and types in the midblock. The applied type (3.C) suggests an integration of any available public open spaces with green street stormwater facilities. The integration can enhance the experience in a community by improving walkability, providing gathering spaces, effective stormwater treatment with connected system, and more. Other applications (4.A, 4.B, 4.C, 4.D, 4.E, 4.F) are additional design features that can be integrated within green streets for providing multifaceted benefits for users.

These typologies can be understood as a form-based implementation tool that can be systematically referred by designers and planners during the green street design processes. The implementation tool emphasizes on the importance of addressing multiple benefits while treating stormwater efficiently. Table 5 is provided to help better understanding of green street typology developed in this paper with more descriptions and constructed green street project samples for each typology.

When planning and designing green streets, it is important to note that street elements (e.g., roads, sidewalks, structures, furniture, buildings, and users) also need to be considered along with the application of stormwater treatment facilities (e.g., planter type, swale type) because street's contexts differ from one another while current manuals tend to focus primarily on the stormwater facilities instead. It is not easy to standardize design applications that can deliver certain benefits since every site has its own unique conditions, and an approach that may be suitable for one location could potentially inhibit some of the multiple potential green street benefits in another location. Thus, typologies in this study are an important tool for communicating among planners and the public: They consider standardized designs but also offer flexibility concerning adaptive design application and the considerations of the different conditions and needs of each site. 
Table 5. Green street typology with descriptions.

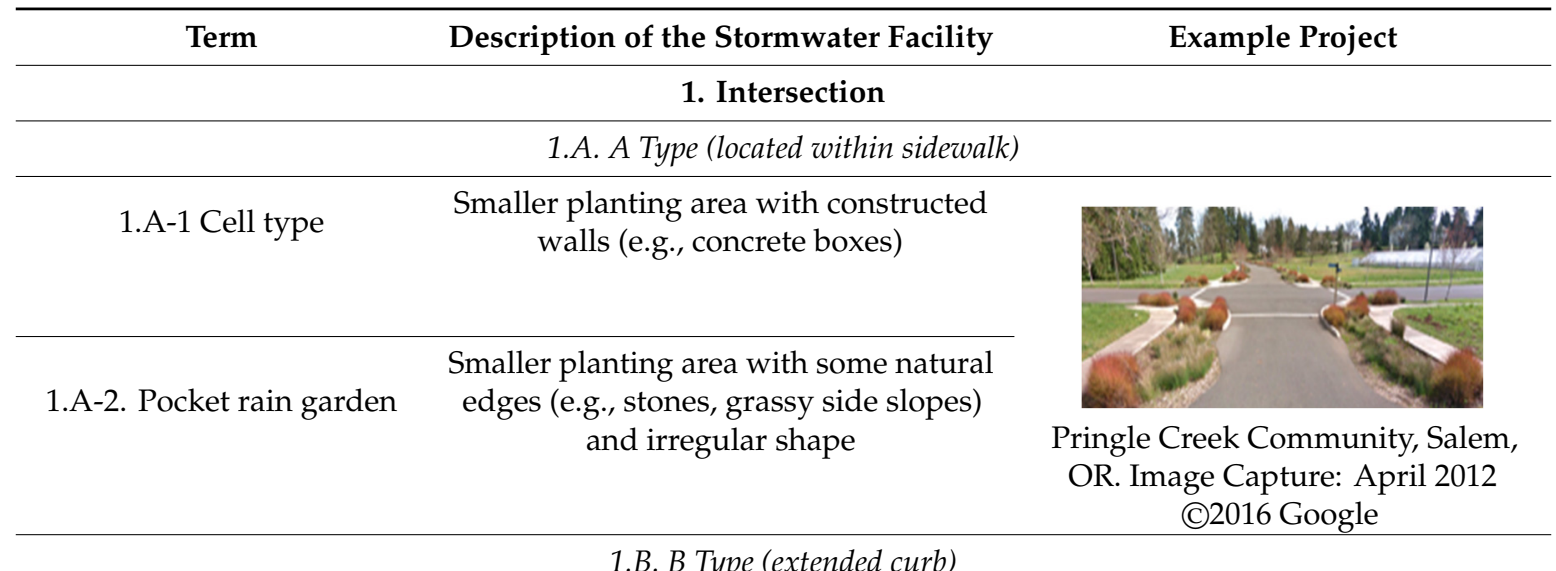

1.B. B Type (extended curb)

1.B-1. Extended curb: Smaller planting area with constructed a type, $b$ type walls (e.g., concrete boxes)

Smaller planting area with some natural

1.B-2. Pocket rain garden edges (e.g., stones, grassy side slopes) and irregular shape (e.g., traffic island)

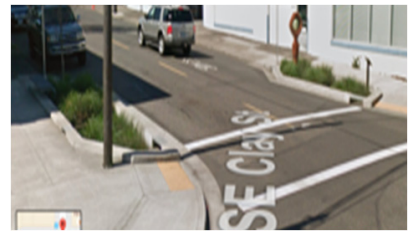

SE Clay St Green Street, Portland,

OR. Image Capture: Mar 2016 (C)2016 Google

\begin{tabular}{ccc}
\hline \multicolumn{3}{c}{ 1.C. C Type (detached from sidewalk) } \\
\hline 1.C-1. Island & Located in the middle of the road & Roundabout, col-de-sac \\
\hline 2. Midblock & \\
\hline
\end{tabular}

\section{A. A Type (within sidewalk)}

2.A-1. Cell type: Planter

Smaller planting area with constructed (raised) walls (e.g., concrete boxes)

2.A-2. Cell type: Natural

Smaller planting area with some natural edges (e.g., stones, grassed side slopes) and irregular shape

Linear planting area with constructed walls (e.g., concrete boxes)

2.A-3. Swale type: Planter

Linear planting area with some natural

2.A-4. Swale type: Natural edges (e.g., stones, grassy side slopes) and irregular shape

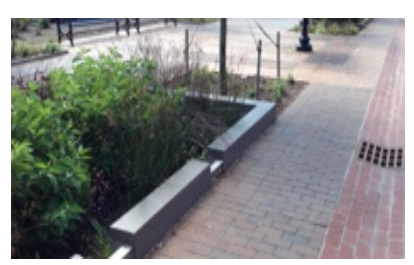

College Ave Promenade, Blacksburg, VA

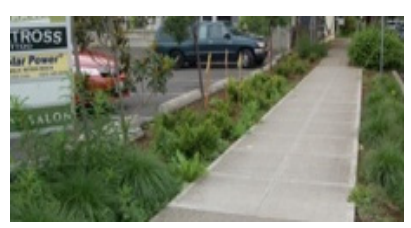

Seven Corners New Seasons Market stormwater planter, Portland, OR

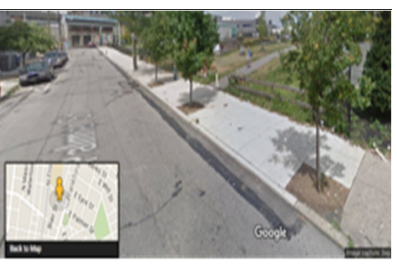

Tree Trench at W Palmer St. (C)2016 Google 
Table 5. Cont.

\begin{tabular}{|c|c|c|}
\hline Term & Description of the Stormwater Facility & Example Project \\
\hline \multicolumn{3}{|c|}{ 2.B. B Type (extended curb) } \\
\hline \multirow[t]{2}{*}{ 2.B-1. Extended curb } & $\begin{array}{l}\text { Smaller planting area with constructed } \\
\text { walls (e.g., concrete boxes) }\end{array}$ & 1.w. \\
\hline & & NE Siskiyou Street, Portland, OR \\
\hline \multicolumn{3}{|c|}{ 2.C. C Type (detached from sidewalk) } \\
\hline \multirow[t]{2}{*}{$\begin{array}{l}\text { 2.C-1. Median: } \\
\text { Constructed/natural edges }\end{array}$} & $\begin{array}{l}\text { Median planting area with constructed } \\
\text { walls (e.g., concrete boxes) or natural } \\
\text { edges (e.g., stones, grassed side slopes) }\end{array}$ & \\
\hline & & $\begin{array}{c}\text { Patrick Henry Drive Green Street, } \\
\text { Arlington, VA }\end{array}$ \\
\hline \multicolumn{3}{|c|}{ 3. Combination (Intersection + Midblock) } \\
\hline $\begin{array}{l}\text { 3.A. A Type Combination } \\
\text { (within sidewalk) }\end{array}$ & Combined type located within sidewalk & Large scale application \\
\hline $\begin{array}{l}\text { 3.B. B Type Combination } \\
\text { (extended curb) }\end{array}$ & Combined type extended from curb & Large scale application \\
\hline 3.C. Applied Type & $\begin{array}{l}\text { Planting area connected to open space, } \\
\text { plaza, park, garden, etc. }\end{array}$ & Integrated system \\
\hline
\end{tabular}

\section{Others}

\begin{tabular}{|c|c|c|}
\hline 4.A. Permeable paving & $\begin{array}{c}\text { Permeable paving for pedestrian or } \\
\text { vehicular roads }\end{array}$ & $\begin{array}{l}\text { Permeable asphalt, permeable } \\
\text { concrete, permeable pavers }\end{array}$ \\
\hline 4.B. Runnel (open/covered) & Rainwater conveyance & Runnel in planter or sidewalk \\
\hline $\begin{array}{c}\text { 4.C. Cistern } \\
\text { (above/underground) }\end{array}$ & $\begin{array}{c}\text { Rainwater harvesting for reuse } \\
\text { (e.g., irrigation) }\end{array}$ & $\begin{array}{l}\text { Cistern connected to the } \\
\text { stormwater facility }\end{array}$ \\
\hline 4.D. Fountain & $\begin{array}{l}\text { Located on slopes or designed for } \\
\text { ornamental purposes }\end{array}$ & Cascades, fountain \\
\hline 4.E. Street furniture & Furniture to support site users & $\begin{array}{l}\text { Benches, light fixtures, } \\
\text { information kiosk }\end{array}$ \\
\hline 4.F. Structure (shade/wall) & $\begin{array}{l}\text { Spatial composition or safety } \\
\text { consideration }\end{array}$ & Shade structures, walls, seat walls \\
\hline
\end{tabular}

\section{Discussion}

As demonstrated by the thirty-five identified benefits from the manuals, green streets need to be understood as a multifaceted and comprehensive street improvement/sustainable development approach. The following figures (Figure 3) present suggested application of green streets reflecting the typologies identified from the previous chapter with the most common typologies found in the constructed green streets such as cell type stormwater planter (2.A-1), cell type natural (2.A-2), median (2.C-1), extended planter (2.B-1), which were found to be popular in the forty-five green street cases when types of green street application to cities' right-of-way was investigated (Table A1). 

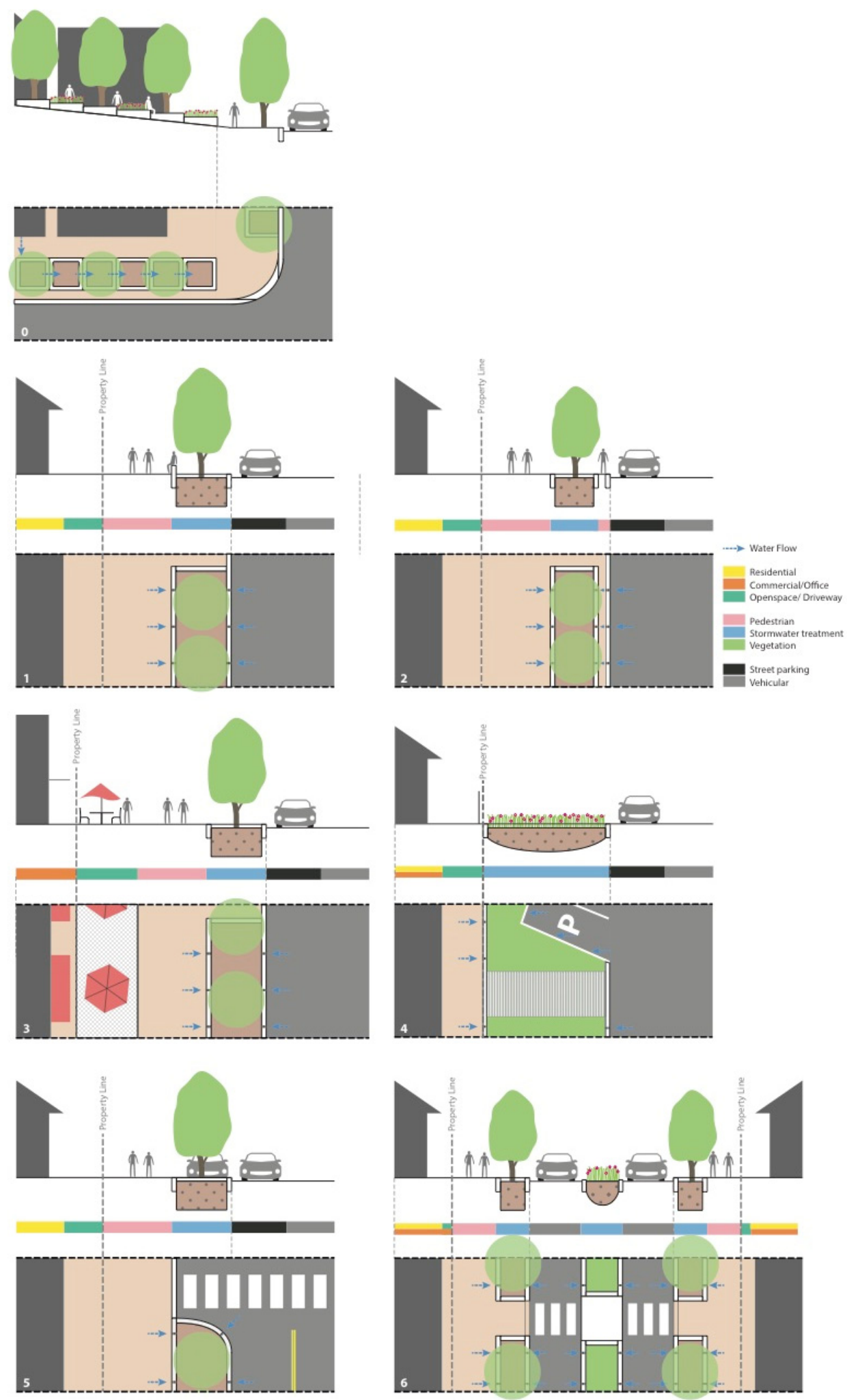

Figure 3. Examples of green street practice [41] (Modified from pp. 601-601): 0. Green street on slope with planter type cascades; $\mathbf{1}$. Green street with wider sidewalk and seat wall; 2 . Green street with wider sidewalk and landing space for street parking; 3 . Green street with outdoor activity area in conjunction with sidewalk; 4 . Green street with wider and leveled stormwater planter, access to the building, and diagonal parking space; 5 . Green street with extended stormwater planter for traffic calming; 6. Green street with stormwater planter in median for safe crossing. 
These examples show ways to apply different types of green streets into various street settings to create a more walkable and safer environment for users by utilizing available spaces within the right-of-way. The examples are not to represent a certain scale but to demonstrate different compositions of various green street elements visually and specific dimensions are to be determined by available spaces, amount of stormwater runoff from catchment areas, users' needs, and more. It should be discussed that design standards in the majority of the manuals seldom include site context objects such as buildings, street furniture, or dimensions of the sidewalk/roadway, along with other factors that support users' activities. In order to have stormwater planters/swales on streets, a certain amount of space including a pedestrian path is required. Moreover, stormwater treatment facilities need to perform infiltration, provide planting beds, and incorporate underdrain pipes if necessary, and most of all, it should allow the stormwater to be collected in the facility with an opening toward catchment areas. Consequently, for green street practices in particular, underground conditions need to be investigated through on-site inspections because they can differ from what is recorded in existing documentation. If space is insufficient for the subgrade portion of a green street project, it cannot be implemented in the first place. Thus, not only the surface areas of a site, but also its underground conditions (i.e., whether it has a shallow groundwater level and bedrock layers or underground utilities) must be taken into account to ensure the success of a green street project.

This paper mostly deals with green street projects in the US and further study can include case study projects from different countries of various cultures and policies to implement green streets, thus expanding the scope of investigation. Moreover, it must be noted that 'green street' is not a universally adopted term around the world to describe sustainable street improvement with stormwater management consideration, hence the term needs to be redefined to be more inclusive for the further research. The findings from this paper will contribute to the knowledge database for green street implementation and the developed typology can be utilized as a system to analyze the diverse sample projects with more multifaceted green street approaches (unique aspects) as well as similar approaches (common aspects) of case study projects around the world. Table 6 shows various features of the case studies in the US, Germany, and South Korea as an example for further research. All projects are implemented on residential streets with green street applications that can be categorized with the typology developed in this paper. However, integrated features can be different as shown in the table: The green street in the US has a flush curb to allow the stormwater runoff to flow into the system as well as parking spaces to accommodate the neighbors' needs [42]. The green street project in Germany is simple but practical with reflection poles for vehicular safety and a series of planters implemented along the street for traffic calming effects [43]. The green street project in Korea has a planter type stormwater facility collecting roof stormwater runoff. The stormwater is stored in a tank and pumped automatically to an adjacent planter with a drought detection sensor. This unique automated watering system is operated by solar power. The wall trellises are used for greening the wall for the narrow street [44]. These examples suggest that further research can present diverse features integrated with green street applications, which will help designers and planners to come up with more effective and creative strategies that can be applied to complex and place-sensitive sites. Its focus will be on multifaceted benefits that green streets can provide rather than solely engineering solutions for stormwater runoff from the street. 
Table 6. An example of further research: Green street projects in the US, Germany, and Korea.

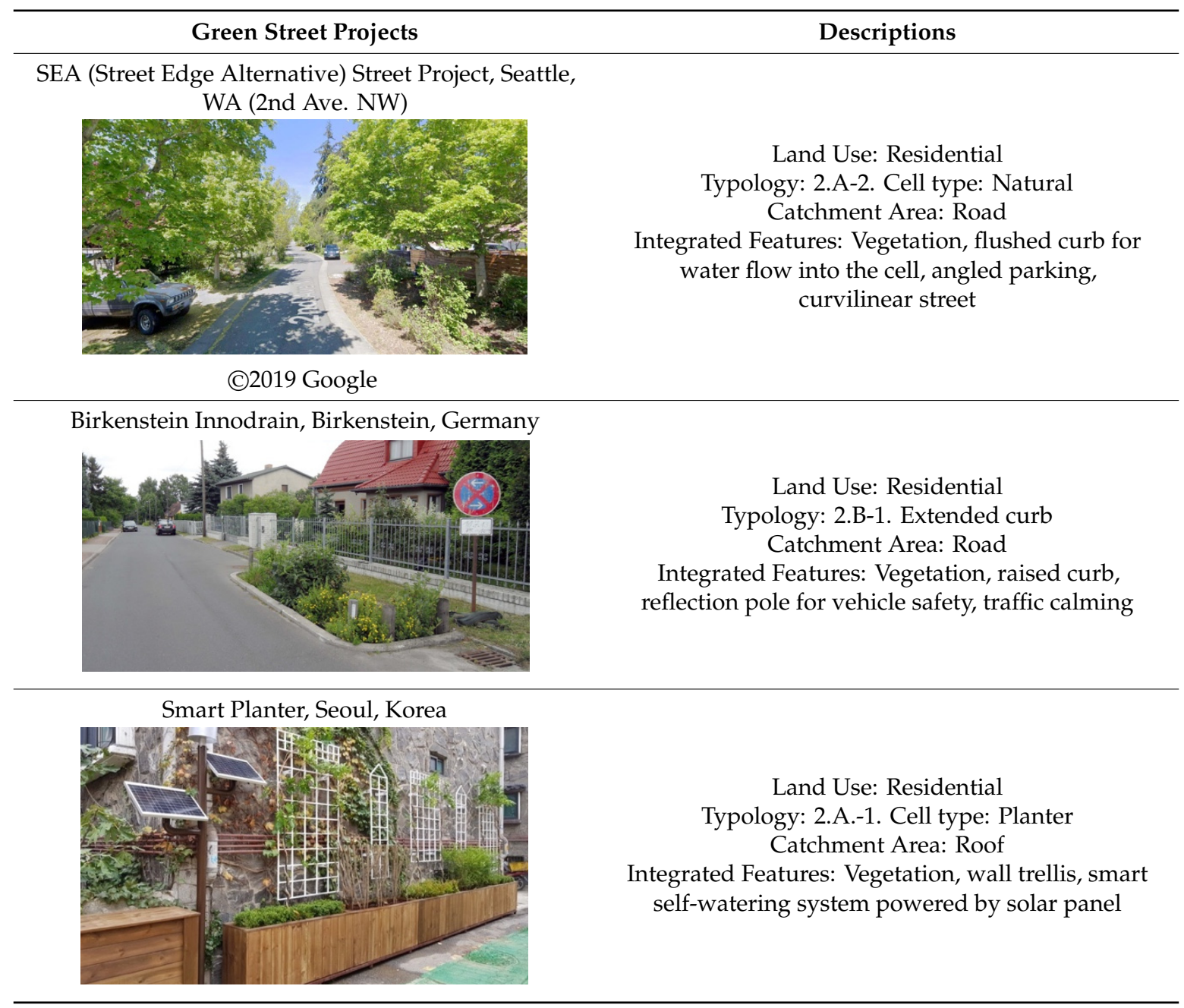

How green streets can be then discussed in the theoretical paradigm of sustainability? Green streets have been implemented primarily to manage stormwater runoff as one of the strategies of green (stormwater) infrastructure in the built environment in the US. The term green street has been "adopted by many cities to refer to streets that emphasize environmental quality in numerous ways, including reducing pavement widths, increasing tree planting, and incorporating stormwater treatment" [45] (p. 83). However, this stormwater management function is only one component of green streets. For instance, the City of Seattle's definition of green streets in its 'Right-of-way Improvement Manual' [29] includes considerations such as promoting pedestrian-oriented streets, enhancing open spaces, managing traffic speed, and adapting to individual localities. Stormwater treatment is mentioned in the manual, but only as one of the possible applications of a green street system, along with solar access, the preservation of historic buildings or street features, and better utilization of the topographical conditions of the site. The other manuals and reports on green streets and green infrastructure that were discussed earlier also describe multifunctional applications of green streets in a community, primarily including their ability to deal with stormwater. Considering this fact, studies of definitions and multiple potential benefits indicate that green streets need to be understood as satisfying a number of diverse strategic characteristics, which can be categorized by three incremental scales in terms of their developmental paradigm: A strategy for stormwater treatment (targeted narrower development strategy), a strategy for green infrastructure (integrated development strategy), and a strategy for sustainable development (inclusive optimal development strategy). Along with the characteristics presented by green streets, it is critical that green street functions as a street need to be 
understood in the context of street systems. The following subsections include discussions on these two views.

First, as observed in the previous sections, stormwater treatment function is one of the critical elements that green streets provide. As a component of stormwater treatment systems, green streets are usually integrated with stormwater best management practices (BMPs), such as storm tree planters, bioswales, and permeable paving. BMPs are effective treatments for the improvement of stormwater quantity and quality that utilize "natural drainage mechanisms" with "the infiltration and storage properties of semi-natural features" [46] (p. 17). The Virginia Runoff Reduction Method lists the following possible BMPs [47]:

- Reducing treatment volume and pollutants: Vegetated roof, rooftop disconnection, permeable pavement, grass channel, dry swale, bioretention, infiltration, extended detention pond, sheet flow to filter/open space;

- Reducing pollutants: Wet swale, filtering practices, constructed wetland, wet ponds, manufactured BMP.

In the US cities, extensive tracts of natural lands have been converted into impervious surfaces due to urban development, and these prevent stormwater runoff from infiltrating into the ground [48]. Without some consideration of where and how runoff flows, problems such as polluted water, erosion, and flooding will eventually arise [49]. Thus, green streets can provide effective networks for stormwater runoff conveyance and release, especially when implemented in environmentally sensitive areas with those issues.

Second, green streets pursue the objectives of the green infrastructure approach —which recognizes the larger scope of environmental issues in addition to BMPs when treating stormwater runoff. Boyle et al. described green infrastructure as "natural and engineered ecological systems which integrate with the built environment to provide the widest possible range of ecological, community and infrastructure services" [50] (p. 5). Similarly, Benedict and McMahon stated that green infrastructure is "an interconnected network of natural areas and other open spaces that conserves natural ecosystem values and functions, sustains clean air and water, and provides a wide array of benefits to people and wildlife. ... [It] is the ecological framework for environmental, social, and economic health" [51] (p. 1). Others have suggested that when green streets are considered for treating stormwater, a watershed approach needs to be adopted, without regard for political boundaries. On-site treatment to enable effective protection of the water quality and protect downstream sites is important, and the plans should consider human health and property as well as ecological preservation [52,53].

The American Society of Landscape Architects has described green infrastructure as "a conceptual framework for understanding the 'valuable services nature provides the human environment" " [54]. The ASLA also characterizes green infrastructure on three scales: (1) At the national or regional level, with a consideration of networks of parks and wildlife corridors; (2) at the urban level, with a consideration of parks and urban forestry as ecologically central hubs; and (3) at the level of buildings, with a consideration of smaller applications such as green roofs and green walls. The ASLA also cites multiple benefits of green infrastructure, such as reducing energy use, improving water and air quality, decreasing solar heat within a city, providing a wildlife habitat, controlling floods, reducing the cost of stormwater treatment facilities and preventing erosion [54]. As one constituent component of green infrastructure recommended by the US EPA, green streets are considered to provide those multiple benefits rather than focusing on only stormwater treatment. Green streets should be applied as a network, reflecting local needs. They play an important role in the larger landscape as a way of improving and protecting the built and natural environments to which the larger ecological conception is applied.

Lastly, green streets can be discussed in the context of sustainable development. Sustainable development follows a holistic approach that promotes balance between human settlements and natural environments in planning processes. The United Nations defined sustainable development in their report, Our Common Future, as a development that "meet[s] the needs of the present 
without compromising the ability of future generations to meet their own needs" [55] (p. 37). Similarly, the Department for Environment, Transport and the Regions (DETR) in the UK defined it as follows: "sustainability is about ensuring a better quality of life for everyone-now and for generations to come" [56]. These definitions do not mention a specific scope for the concept of sustainable development, although it can be inferred that sustainable development is extensively interconnected with phenomena on the earth that are caused by humans and nature. Other descriptions of sustainable development note that it is "elusive ... [but] important and does deserve attention.... the core of the idea of sustainability is the concept that current decisions should not damage prospects for maintaining or improving living standards in the future" [57,58] (p. 716). Ritchie and Thomas have described sustainability in urban design as planning a city with more consideration for people. In this sense, "creating pedestrian, cyclists and public transport is a key aspect of sustainable development" [59] (p. 3), a clear contrast to existing built environments that are overwhelmingly automobile oriented. Ritchie and Thomas have described two more aspects of urban sustainability: making a city greener for biodiversity as well as for the well-being of humans and creating a more delightful environment to keep people "secure and happy" [59] (p.3). The specific scope of sustainable elements can be described as follows: "1) To protect natural resources, 2) to use resources efficiently, 3) to strengthen the sense of community, and 4) to consider the regional context" [51]. Moreover, sustainable development is frequently recognized as development that is "ecologically sustainable or environmentally sound" [60,61] (p. 608). Consequently, successful achievement and balance among three aspects of sustainability-economy, environment, and society [55] —in the larger scope of the environment can be promoted by adopting a sustainable development approach, which green streets potentially and optimally aim for.

In conclusion, sustainable urban development does not always include a green infrastructure approach, and a green infrastructure approach does not always include stormwater management considerations (Figure 4). However, the planning and implementation of stormwater management and a green infrastructure do need to be discussed in the context of sustainability, where sustainability means more holistic and renewable strategies for improving and protecting a built and natural environment. As Odum has stated, humans have forgotten that ultimately, they depend for everything on nature, and they are likely to continue to forget this "as long as life support services [from nature] are considered free" [62] (p. 3). Therefore, pursuing sustainable development does not just involve taking into account the well-being of humans or the reclamation of one part of a river corridor but is more about realizing how the elements of an environment are integrated on a larger scale. When we are planning and developing new projects, we need to realize what kind of impact we ourselves, as parts of the environment, will have on the whole environmental system. In this sense, sustainability does not always mean green, but green tries to achieve sustainability.

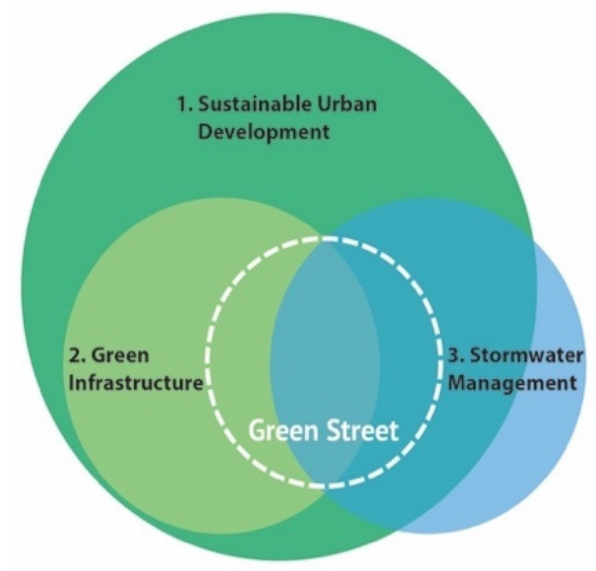

Figure 4. Green street in three development paradigms. 
As an element of green infrastructure, an ideal green street project seems to be one that is designed using a complex strategy for pursuing sustainability. It can "act as a synthesis of a number of other areas of planning (greenways, green spaces, high-density planning) to promote a coherent discipline for future development" [55] (p. 24). Therefore, green streets should be designed differently from a conventional stormwater treatment system, which is solely designed to target a very specific goal such as reducing stormwater runoff or preventing local flooding. The multiple objectives of sustainable development are the ultimate goal for green streets in relation to a given site. This means that green streets need to emphasize a network system approach that can successfully integrate multifunctional disciplines to promote their influence throughout the site.

\section{Conclusions}

While various definitions of the concept were identified in the previous chapter, green streets are most commonly described as an effective and affordable tool that treats stormwater with plants and soils pursuing multiple benefits for the better quality of life. Green streets embrace stormwater runoff as a resource to do more rather than treating it as harmful waste. Thus, green streets differ from conventional streets because they include stormwater treatment facilities and emphasize multiple benefits such as promotion of pedestrian safety and aesthetic qualities of the environment by incorporating larger (permeable) landscape areas and narrower roads. Types of stormwater treatment facilities vary according to the needs of specific locations and the available space in the right-of-way. Thus, green streets can be considered as a sustainable development approach, fulfilling a variety of environmental, social, and economic objectives so that cities may be more apt to implement green streets with a reduced concern for overconsuming resources. They also maintain all functions of conventional streets by forming the image of a city, connecting destinations, and improving the flow of water. This naturally leads to the study of urban livability at the street level. Green streets should be understood as an approach with multiple visions which include stormwater treatment, green infrastructure, and sustainable development strategies. Openness to the larger sense of what green street projects entail will enable planners and citizens to realize the potential benefits to surrounding communities and help in the planning and promotion of successful green street applications.

Funding: This research received no external funding.

Acknowledgments: I am grateful to my co-chairs of the dissertation committee, Patrick Miller and Dean Bork, for their extensive guidance and the expert panels from different municipalities who provided professional insight about green street implementation. I also thank UTA graduate research assistants Melissa Lemuz and Tricia Mikal for their assistance.

Conflicts of Interest: The author declares no conflict of interest.

\section{Appendix A}

Table A1. A list of green street projects collected for developing the form-based green street typology.

\begin{tabular}{ccc}
\hline \multicolumn{1}{c}{ Status } & Green Street Projects & Implemented Typology \\
\hline $\begin{array}{c}\text { Constructed } \\
\text { Projects }\end{array}$ & 21st Street, Paso Robles, CA & 1.B-1. Extended planter: b type, 2.C-1. \\
& Median \\
& Avalon Green Alley Network Project, Los Angeles, CA & 4.A. Permeable paving \\
& Elmer Avenue Neighborhood Project, Los Angeles, CA & 2.A-4. Swale type: Natural \\
& El Cerrito Green Streets Project (First Site) Madison Site, El Cerrito, CA & 2.A-1. Cell type: Planter \\
El Cerrito Green Streets Project (Second Site) Eureka Site, El Cerrito, CA & 2.A-1. Cell type: Planter \\
& Elmer Paseo Stormwater Improvements, Los Angeles, CA & 2.A-4. Swale type: Retention, \\
& 4.A. Permeable paving \\
& Glen Oaks Bioswales and Drywells Project, Los Angeles, CA & 2.A-1. Cell type: Planter \\
& Hacienda Avenue Green Street Improvement Project, Campbell, CA & 2.A-1. Cell type: Planter, 2.B-1. \\
& Extended planter \\
& Malibu Hills Stormwater Enhancement and Green Street Project, & 2.C-1. Median \\
\hline
\end{tabular}


Table A1. Cont.

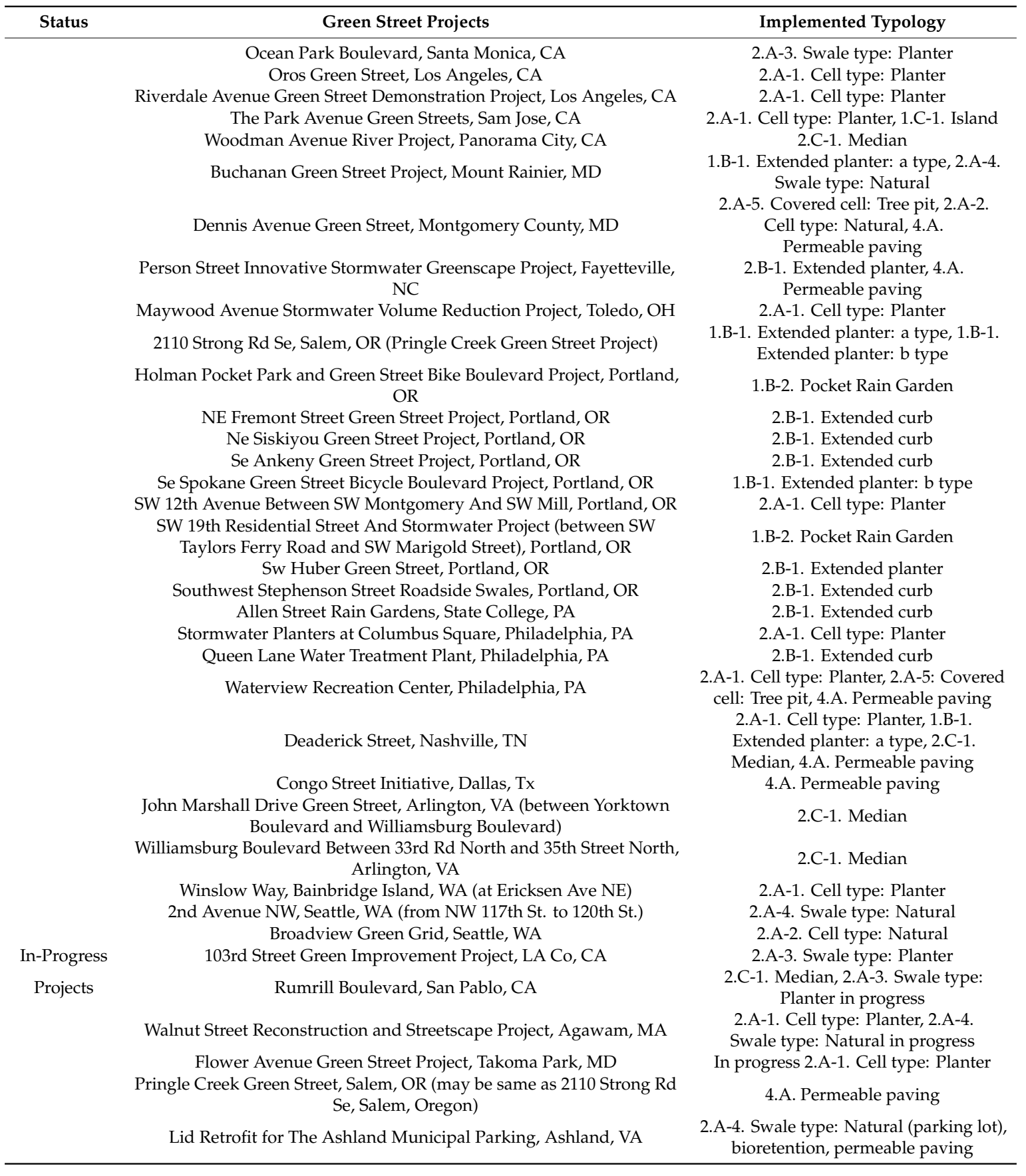

\section{References}

1. Sieber, J.; Pons, M. Assessment of Urban Ecosystem Services using Ecosystem Services Reviews and GIS-Based Tools. Procedia Eng. 2015, 115, 53-60. [CrossRef]

2. Demuzere, M.; Orru, K.; Heidrich, O.; Olazabal, E.; Geneletti, D.; Orru, H.; Bhave, A.G.; Mittal, N.; Feliu, E.; Faehnle, M. Mitigating and Adapting to Climate Change: Multi-Functional and Multi-Scale Assessment of Green Urban Infrastructure. J. Environ. Manag. 2014, 146, 107-115. [CrossRef] [PubMed]

3. Baruch, E.M.; Voss, K.A.; Blaszczak, J.R.; Delesantro, J.; Urban, D.L.; Bernhardt, E.S. Not All Pavements Lead to Streams: Variation in Impervious Surface Connectivity Affects Urban Stream Ecosystems. Freshw. Sci. 2018, 37, 673-684. [CrossRef]

4. Paul, M.J.; Meyer, J.L. Streams in the Urban Landscape. Annu. Rev. Ecol. Syst. 2008, 32, 207-231. [CrossRef] 
5. Zhang, Y.; Odeh, I.O.A.; Han, C. Bi-Temporal Characterization of Land Surface Temperature in Relation to Impervious Surface Area, NDVI and NDBI, Using a Sub-Pixel Image Analysis. Int. J. Appl. Earth Obs. Geoinf. 2009, 11, 256-264. [CrossRef]

6. Winter, H. Making Sense of Multiple Extreme Weather Events. Significance 2017, 14, 6-7. [CrossRef]

7. Hayhoe, K.; Sheridan, S.; Kalkstein, L.; Greene, S. Climate Change, Heat Waves, and Mortality Projections for Chicago. J. Great Lakes Res. 2010, 36, 65-73. [CrossRef]

8. Zhang, W.; Villarini, G.; Vecchi, G.A.; Smith, J.A. Urbanization Exacerbated the Rainfall and Flooding Caused by Hurricane Harvey in Houston. Nature 2018, 563, 384-388. [CrossRef]

9. Tzoulas, K.; Korpela, K.; Venn, S.; Yli Pelkonen, V.; Kazmierczak, A.; Niemela, J.; James, P. Promoting Ecosystem and Human Health in Urban Areas Using Green Infrastructure: A Literature Review. Landsc. Urban Plan. 2007, 81, 167-178. [CrossRef]

10. Beery, T. Engaging the Private Homeowner: Linking Climate Change and Green Stormwater Infrastructure. Sustainability 2018, 10, 4791. [CrossRef]

11. Meerow, S.; Newell, J.P. Spatial Planning for Multifunctional Green Infrastructure: Growing Resilience in Detroit. Landsc. Urban Plan. 2017, 159, 62-75. [CrossRef]

12. American Rivers; The Center for Neighborhood Technology; The Great Lakes and St. Lawrence Cities Initiative. Green Infrastructure Portfolio Standard. Available online: http:/www.mayorsinnovation.org/ images/uploads/pdf/4_-_Green_Infrastructure_Portfolio_Standard.pdf (accessed on 1 August 2019).

13. Copeland, C. Green Infrastructure and Issues in Managing Urban Stormwater; CRS Report; R43131; Congressional Research Service: Washington, DC, USA, 2016.

14. Clean Water America Alliance. Barriers and Gateways to Green Infrastructure; Clean Water America Alliance: Washington, DC, USA, 2011.

15. Kilometers of Public Roads and Streets in the United States by Type of Surface, table $0104 \mathrm{mq418.}$ US Department of Transportation, Bureau of Transportation Statistics. Available online: https://www.bts. gov/content/kilometers-public-roads-and-streets-united-states-type-surface (accessed on 1 July 2019).

16. Southworth, M.; Ben Joseph, E. Streets and the Shaping of Towns and Cities; Island Press: Washington, DC, USA, 2003.

17. Tilley, J.S.; Slonecker, E.T. Quantifying the Components of Impervious Surfaces; Open-File Report; U.S. Department of Transportation, Federal Highway Administration: Washington, DC, USA, 2006.

18. Newell, J.P.; Seymour, M.; Yee, T.; Renteria, J.; Longcore, T.; Wolch, J.R.; Shishkovsky, A. Green Alley Programs: Planning for a Sustainable Urban Infrastructure? Cities 2013, 31, 144-155. [CrossRef]

19. City of Portland. NE Siskiyou Green Street Project; City of Portland: Portland, OR, USA, 2005.

20. Portland Environmental Services. Portland Green Street Program. Available online: https://www. portlandoregon.gov/bes/45386 (accessed on 17 August 2019).

21. City of Arlington. Green Streets. Available online: https://projects.arlingtonva.us/programs/stormwatermanagement/green-streets/ (accessed on 17 September 2019).

22. Environmental Protection Agency. What is Green Infrastructure? Available online: http://www.epa.gov/ green-infrastructure/what-green-infrastructure\#greenstreetsandalleys (accessed on 1 November 2018).

23. City of Philadelphia. City of Philadelphia Green Streets Design Manual; City of Philadelphia: Philadelphia, PA, USA, 2014.

24. Environmental Protection Agency. A Conceptual Guide to Effective Green Streets Design Solutions; Environmental Protection Agency: Washington, DC, USA, 2009.

25. Water Environment Research Foundation. Green Streets Basics and Design: BMPs to Programs. Available online: https://www.werf.org/liveablecommunities/toolbox/gst_design.htm (accessed on 29 July 2019).

26. Lukes, R.; Kloss, C.; Low Impact Development Center. Municipal Handbook: Green Streets; Managing Wet Weather with Green Infrastructure; EPA-833-F-08-009; US Environmental Protection Agency: Washington, DC, USA, 2008; p. 19.

27. Metro (Portland Metropolitan Area). Green Streets: Innovative Solutions for Storwmater and Stream Crossings; Metro: Portland, OR, USA, 2002.

28. National Association of City Transportation Officials. NACTO Urban Street Design Guide Overview; National Association of City Transportation Officials: New York, NY, USA, 2012.

29. Seattle. Seattle Right-Of-Way Improvements Manual. Available online: http://www.seattle.gov/rowmanual/ manual/6_2.asp (accessed on 1 December 2018). 
30. Dumbaugh, E.; Gattis, J.L. Safe Streets, Livable Streets. J. Am. Plan. Assoc. 2005, 71, 283-300. [CrossRef]

31. Schueler, T.R.; Fraley McNeal, L.; Cappiella, K. Is Impervious Cover Still Important? Review of Recent Research. J. Hydrol. Eng. 2009, 14, 309-315. [CrossRef]

32. Yin, R.K. The Case Study as a Serious Research Strategy. Knowl. Creat. Diffus. Util. 1981, 3, 97-114. [CrossRef]

33. Pioneer Valley Planning Commission. Pioneer Valley Sustainability Toolkit; PVPC: Springfield, MA, USA, 2015.

34. District Department of Transportation. Greening DC Streets: A Guide to Green Infrastructure in the District of Columbia; District Department of Transportation: Washington, DC, USA, 2014.

35. Carlson, M.; Caughey, W.; Ward, N. Green Streets Guidebook for the City of Holyoke, Massachusetts; City of Holyoke: Holyoke, MA, USA, 2014.

36. City of Cleveland. Cleveland Complete and Green Streets; City of Cleveland: Cleveland, OH, USA, 2013.

37. Chicago Department of Transportation. The Chicago Green Alley Handbook: An Action Guide to Create a Greener, Environmentally Sustainable Chicago; Chicago Department of Transportation: Chicago, IL, USA, 2010.

38. Ratner, C. Cultural Psychology: Theory and Method; Kluwer Academic/Plenum Publishers: New York, NY, USA, 2002.

39. City of New York; Department of Environmental Protection; Bureau of Engineering Design and Construction. Standard Designs and Guidelines for Green Infrastructure Practices; NYC Environmental Protection: New York, NY, USA, 2017.

40. Portland Environmental Services. City of Portland Stormwater Management Manual; City of Portland: Portland, OR, USA, 2016.

41. Im, J. A Study of the Planning and Design Process of Green Infrastructure Focusing on Green Street Approach: Guidance to Successful Implementation. In Future Resilience; International Federation of Landscape Architects: Singapore, 2018; pp. 594-603.

42. Matsuno, H.; Chiu, S. SEA Street. Seattle, USA. Available online: https://nacto.org/wp-content/uploads/2015/ 04/stormwater_management_challenge_matsuno.pdf (accessed on 22 October 2019).

43. Birkenstein Innodrain. From Sieker: The Stormwater Experts Website. Available online: https://www. sieker.de/en/projects-and-references/planning-projects/project/birkenstein-innodrain-32.html (accessed on 10 October 2019).

44. Im, J.; Guerrero, M.; Condon, D. ReThinking Small Alleys: A Path to Big Hope. In Proceedings of the 2018 ASLA Conference on Landscape Architecture, Philadelphia, PA, USA, 19-22 October 2018.

45. Girling, C.; Kellett, R. Skinny Streets and Green Neighborhoods: Design for Environment and Community; Island Press: Washington, DC, USA, 2005.

46. Butler, D.; Davies, J.W. Urban Drainage, 3rd ed.; Spon Press: New York, NY, USA, 2011.

47. Virgina Water Permitting Division. Virginia Runoff Reduction Method; Commonwealth of Virginia Department of Environmental Quality Water Permitting Division: Richmond, VA, USA, 2016.

48. Bowles, G. Impervious Surface-An Environmental Indicator. Land Use Educ. 2002, 1-2.

49. Sung, C.Y.; Yi, Y.; Li, M.H. Impervious Surface Regulation and Urban Sprawl as Its Unintended Consequence. Land Use Policy 2013, 32, 317-323. [CrossRef]

50. Boyle, C.; Gamage, G.B.; Burns, B.; Knight Lenihan, S.; Schwendenmann, L.; Thresher, W. Greening Cities: A Review of Green Infrastructure; University of Auckland: Auckland, New Zealand, 2014.

51. Benedict, M.A.; McMahon, E.T. Green Infrastructure: Linking Landscapes and Communities; Island Press: Washington, DC, USA, 2006.

52. Randolph, J. Environmental Land Use Planning and Management; Island Press: Washington, DC, USA, 2004.

53. Roy, A.H.; Wenger, S.J.; Fletcher, T.D.; Walsh, C.J.; Ladson, A.R.; Shuster, W.D.; Thurston, H.W.; Brown, R.R. Impediments and Solutions to Sustainable, Watershed-Scale Urban Stormwater Management: Lessons from Australia and the United States. Environ. Manag. 2008, 42, 344-359. [CrossRef]

54. American Society of Landscape Architects. Green Infrastructure: Over View. Available online: https: //www.asla.org/ContentDetail.aspx?id=43532 (accessed on 4 April 2018).

55. United Nation. Our Common Future; Oxford University Press: Oxford, UK, 1987.

56. Mell, I.C. Can Green Infrastructure Promote Urban Sustainability? Proc. Inst. Civ. Eng. Eng. Sustain. 2009, 162, 23-34. [CrossRef]

57. Brown, B.J.; Hanson, M.E.; Liverman, D.M.; Merideth, R.W. Global Sustainability: Toward Definition. Environ. Manag. 1987, 11, 713-719. [CrossRef] 
58. Pearson, C. Down to Business: Multinationals, the Environment and Development; World Resources Institute: Washington, DC, USA, 1985.

59. Ritchie, A.; Thomas, R. Sustainable Urban Design: An Environmental Approach; Taylor Francis: London, UK; New York, NY, USA, 2009.

60. Lele, S.M. Sustainable Development A Critical Review. World Dev. 1991, 19, 607-621. [CrossRef]

61. Tolba, M.K. The Premises for Building a Sustainable Society_Address to the World Commission on Environment and Development; United Nations Environment Programme: Nairobi, Kenya, 1984.

62. Odum, E.P. Fundamentals of Ecology, 5th ed.; Thomson Brooks/Cole: Belmont, CA, USA, 2005.

(C) 2019 by the author. Licensee MDPI, Basel, Switzerland. This article is an open access article distributed under the terms and conditions of the Creative Commons Attribution (CC BY) license (http://creativecommons.org/licenses/by/4.0/). 